\title{
A first study of the millstones of the Greek Colony of Megara Hyblaea (Sicily)
}

\author{
Chloé Chaigneau
}

\begin{abstract}
Megara Hyblaea, one of the first Greek settlements in Sicily, has a large and diverse assemblage of millstones: saddle querns, Olynthus mills, Morgantina mills, Delian mills, rotary querns and possibly a Pompeian mill. This diversity of mill types is the result of the long occupation of the site and the confluence in Sicily of Greek, Punic and Roman cultures and a variety of food processing traditions.
\end{abstract}

Keywords: Megara Hyblaea, Saddle quern, Morgantina, Olynthus, Delian, millstone

Chloé Chaigneau, Université Paris 1 Panthéon-Sorbonne (Paris) chloe.chaigneau@univ-paris1.fr, $++330622405035$

\section{Introduction}

The city of Megara Hyblaea, founded in 728 BC, was one of the first Greek colonies in Sicily. It is located on the Bay of Augusta between Catania and Syracuse, just east of the Hyblaean Mountains, between a volcanic district and the sedimentary plateau of Ragusa (Fig. 1). According to ancient texts, the colony was destroyed in $483 \mathrm{BC}$ by Gelon of Syracuse and remained uninhabited until the foundation of a second settlement around 340 BC. This second city remained under the sphere of influence of Syracuse until the Second Punic War. After its destruction by Marcellus in 213 BC, the site remained sparsely occupied until the 6th century AD. The focus of this paper is the study of the site's large assemble of millstones (Fig. 2).

The earliest archaeological work at the site dates to the end of the 19th century. Between 1948 and 1980 the north-western sector of the city was excavated by the French School of Rome resulting in the discovery of a large number (110) of millstones. Unfortunately, the spatial and chronological contexts of the millstones were not recorded. Previous work on millstones in Sicily, besides a few references in site reports or surveys, were undertaken at the inland cities of Morgantina (White 1963) and Entella (Canzanella 1997).

Saddle querns are characteristic of the earliest, longest and the most active occupation of Megara Hyblaea. It is interesting that the number of lower stones of both saddle querns and Olynthus mills far outnumber their respective upper stones. Furthermore, their quantity cannot always be determined due to their fragmentary state. Among the larger rotary millstones are ten Morgantina models corresponding to at least six different mills, 18 Delian millstone segments corresponding to at least eight mills, and four small cylindrical rotary querns. Although the nature of a single large bell- 


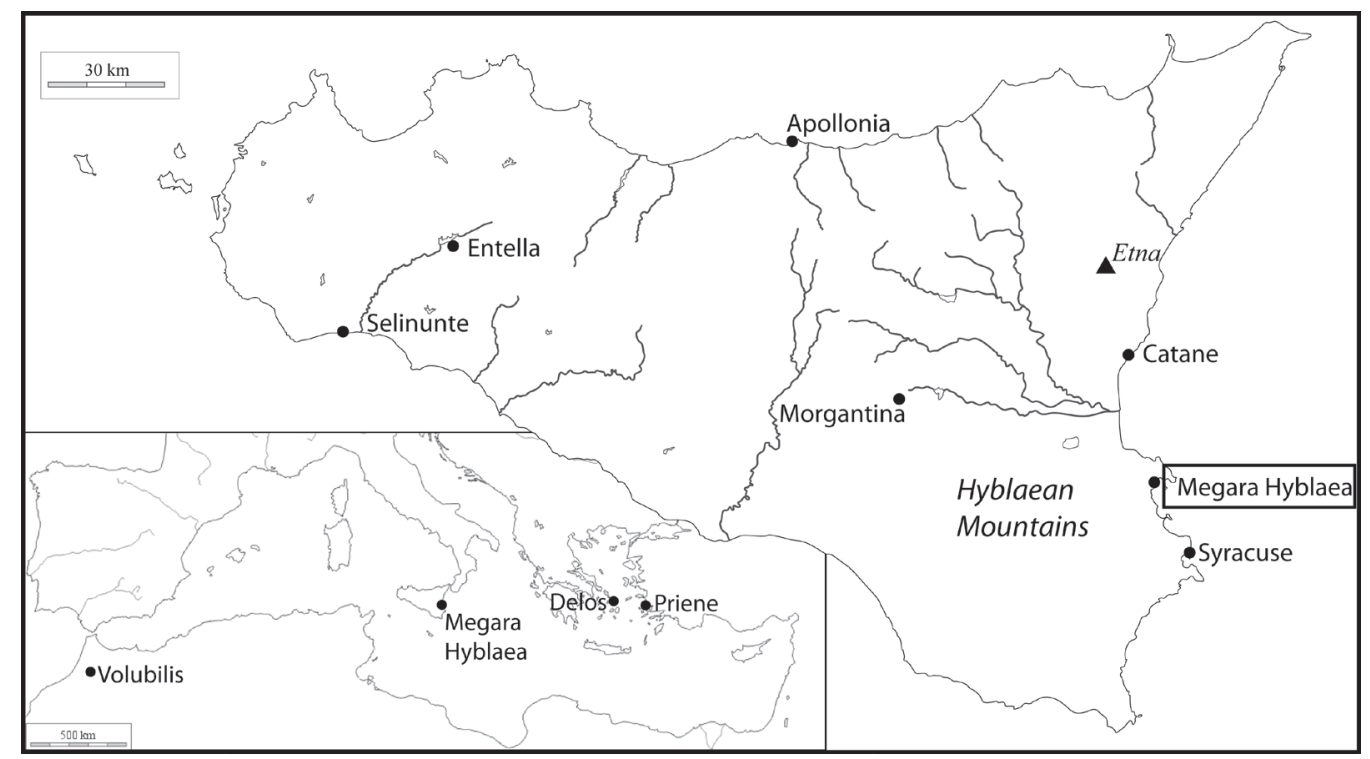

Fig. 1: Megara Hyblaea on the eastern coast of Sicily and sites mentioned in the text.

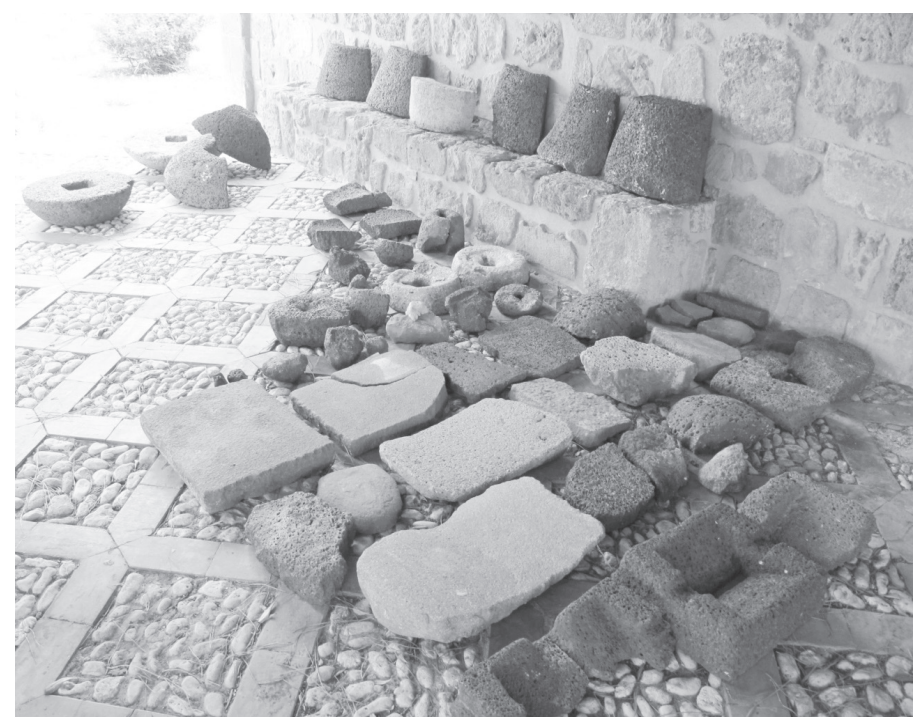

Fig. 2: View of the Megara Hyblaea millstone assemblage (photograph by C. Chaigneau).

shaped meta has not been clearly identified, it probably corresponds to a Pompeian mill.

The petrography includes dark vesicular volcanic rocks, sandstones, conglomerates and reddish rhyolites. Only one Morgantina millstone, a rhyolite reputedly from a quarry in Sardinia (WilliamsThorpe 1988, 101), benefitted from petrographical analysis. The provenance of the other stones cannot be established with certainty. One cannot, according to Gluhak and Schwall (2014), even assume that the volcanic stones come from outcrops on the island of Sicily. In any case, all of the upper stones are characterised by a high level of surface finishing and, at times, dressing patterns.

\section{Millstone description and classification}

\section{Saddle querns}

Despite the large number of saddle querns (52, i.e. $43 \%$ of the assemblage), only 11 are whole. They measure between 30 and $40 \mathrm{~cm}$ in length. None can be coupled with another. Except for two cases bearing natural irregularities, every quern is carefully shaped. Several general morphological tendencies emerge.

Among the upper stones (Fig. 3) a distinction can be drawn between two general types. The most common is the regularly shaped, narrow and elongated (elliptical or almond-shaped) represented by no. 008. These range from 13.5 to $16 \mathrm{~cm}$ in width. One-third overlap their lower stones (in French débordants).

The second general type of upper stone, represented by no. 037, is wider (16 to $21 \mathrm{~cm}$ wide) and presents an oval or asymmetrical shape. Three are equipped with protuberances serving as lateral hand grips. One large volcanic quern (50 cm long and $20 \mathrm{~cm}$ wide) has a cutting that served as a grip (040). A unique example is the upper stone (036) with a convex grinding surface. Among the different types of upper stones, the petrography of the rock appears to be irrelevant. 


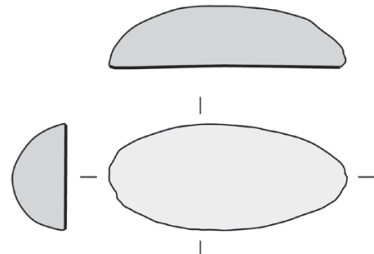

008

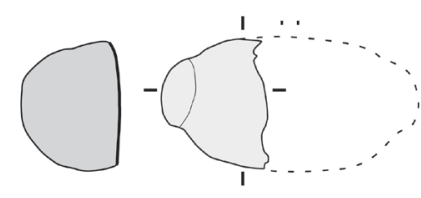

004

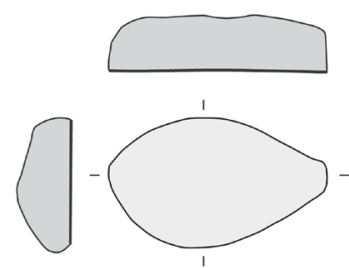

037

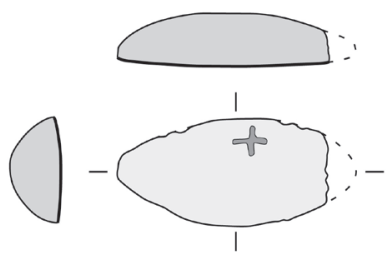

036
099

$-$

108

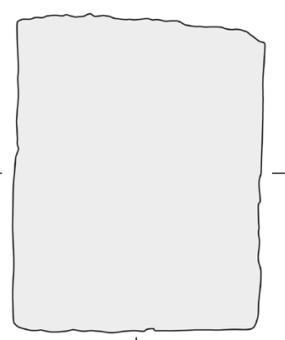

108

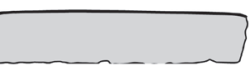

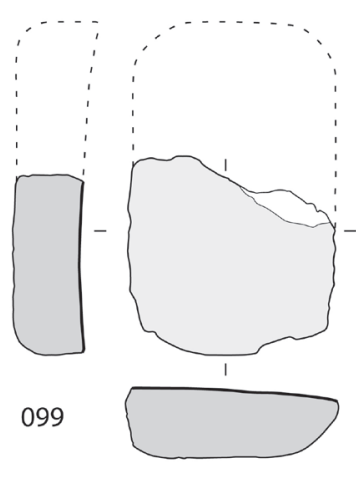

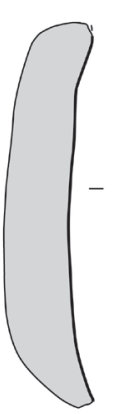

104

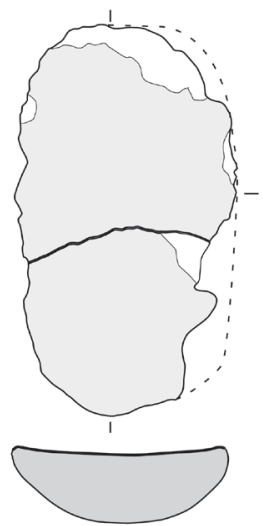

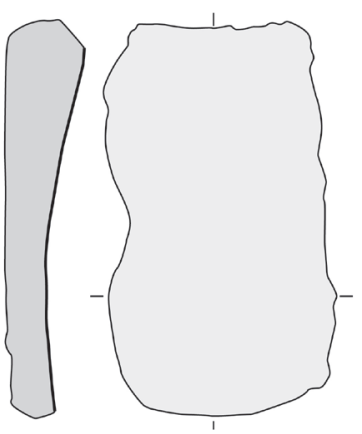

094

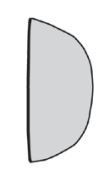

040

C. Chaigneau).

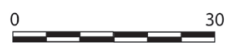

Fig. 4: Main types of lower stones of saddle querns at Megara Hyblaea (drawing by C. Chaigneau).

The lower stones (Fig. 4) are better preserved. We can distinguish four main types following tendencies leading to thinner and more regular shapes. Only one (099) has a concave grinding surface. A second group consists of three thick volcanic lower stones, oval to rectangular in shape, with their back more or less shaped (104). The thirteen other pieces seem to belong to a third group of thinner lower stones of volcanic rock or sandstone, rectangular in shape, with a rather flattened back (094). Among the lower stones are two identical perfectly rectangular and thin fine-grained stones (108).

Although none of these querns were found in situ, it is possible that elongated almond-shaped upper stones were coupled with thin and wide rectangular lower stones. This combination appears to be a typical Archaic Greek, if not Sicilian, form as in the case of the saddle querns discovered at Morgantina (White 1963, 200-02) and Selinunte, a colony founded on the opposite side of Sicily by residents of Megara Hyblaea (Gluhak and Schwall 2014, 4). 


\section{Olynthus mills}

The Olynthus mill (also called hopper rubbers) is represented in Megara Hyblaea by two lower stones and eight upper stones. They are comparable with examples found elsewhere in Sicily in either Greek or other settlements with strong Greek influences (White 1963, 202-203; Canzanella 1997, 254-256; Bonnano 2009, 28) (Fig. 5). Only one upper stone shows a dressing pattern in the form of straight furrows parallel to the hopper, the most common striations pattern (Frankel 2003, 13).

'Sicilian' Olynthus upper stones measure on an average $40 \times 35 \mathrm{~cm}$ and present a characteristic V-shaped central cutting (serving as a hopper) and a square rim. They all bear slots on the short sides at the level of the rim and horizontal cuttings along the middle of the edge. Traces of iron and lead are at times conserved in these cuttings.

These fittings served to secure the driving rig. The cuttings on the short sides seem to be a more resistant alternative to the single, deep perforations present on most Olynthus millstones of the Aegean world (Frankel 2003, 5-6). Only one large and particularly worn example has both slots and grooves on its long sides. These fittings appear to be repairs to reinforce the system of traction and extend the life of the mill. The pattern of wear seems to confirm a mechanism implying a to-and-fro motion.
All of the Olynthus examples are of hard, vesicular volcanic rock. One presents shallow dressing furrows parallel to the slit. The significant wear of the hopper located in the middle area of both faces, indicates that when driven it was subject to high pressure. We assume that there was a device that pushed the grains into the slit. This downward pressure was either activated by the miller or by gravity.

An interesting example is a fragment of what appears to be a saddle quern (c. $30 \times 18 \times 7 \mathrm{~cm}$ ) with a hemispherical cross-section and a central, elongated hopper, roughly hewn from a coarse volcanic rock (Fig. 6). This mill has parallels in the eastern Mediterranean (Frankel 2003, 8). However, contrary to the examples at Priene or Delos, the Megara Hyblaea fragment does not have lateral hand-grips.

This example is possibly a prototype of the 'classical' Olynthus mill. The early phases of development of the Olynthus mill probably began with the carving of the hopper in a saddle quern, followed by a progressive regularisation of the contour and hand-grips. This would be followed by the major improvement, the cuttings for a lever. The chronological context of this unique example does not permit us to identify Sicily as a potential location of invention of the Olynthus mill. It does, however suggest the transfer of this type of mechanism to the western Mediterranean before the elaboration of its final design.
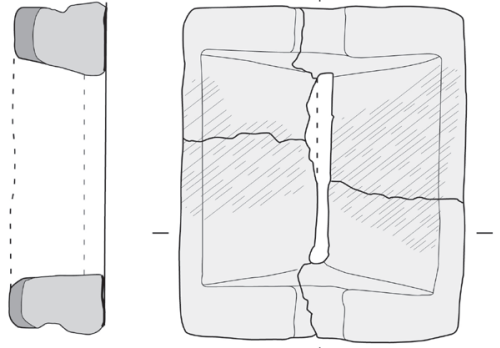

057
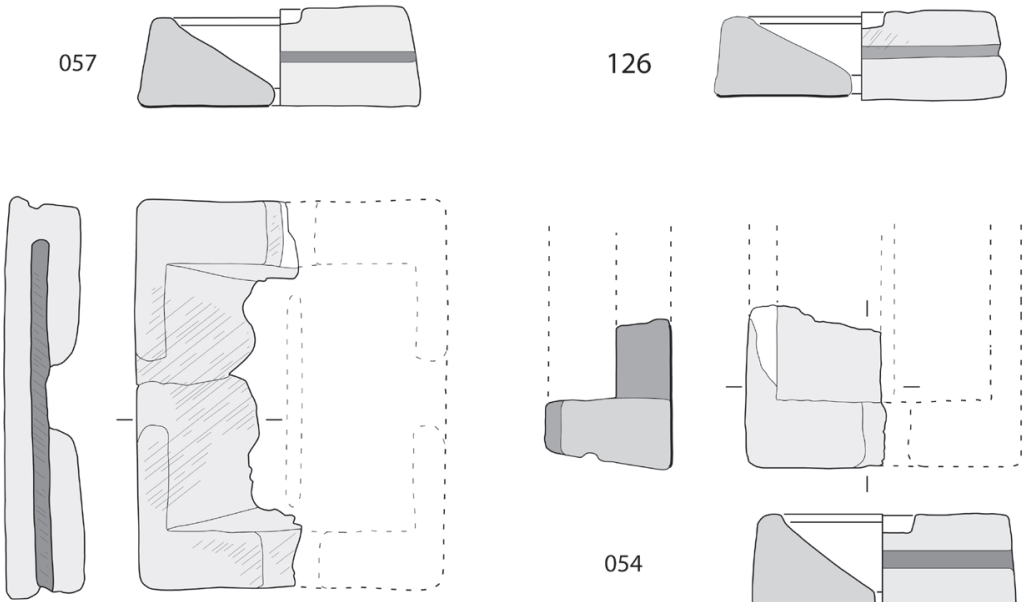

054

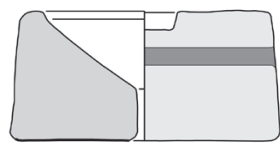

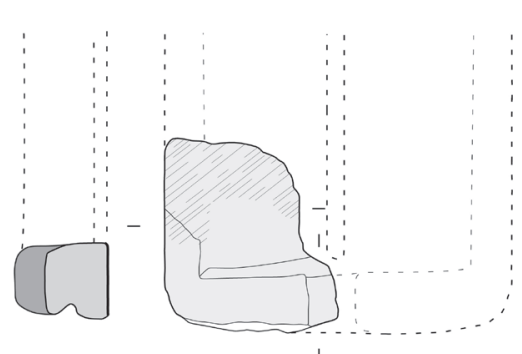

125

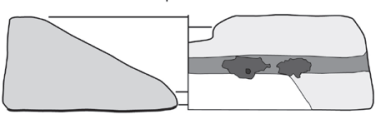

124

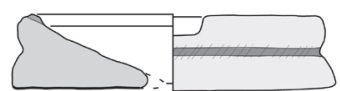

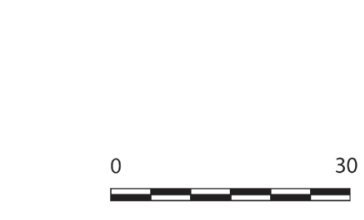
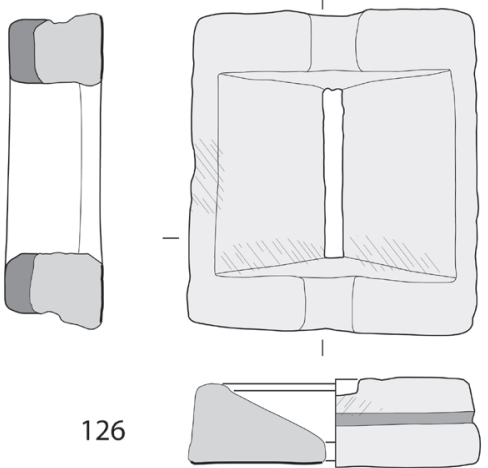

Fig. 5: Examples of an Olynthus mill upper stones (drawing by C. Chaigneau). 


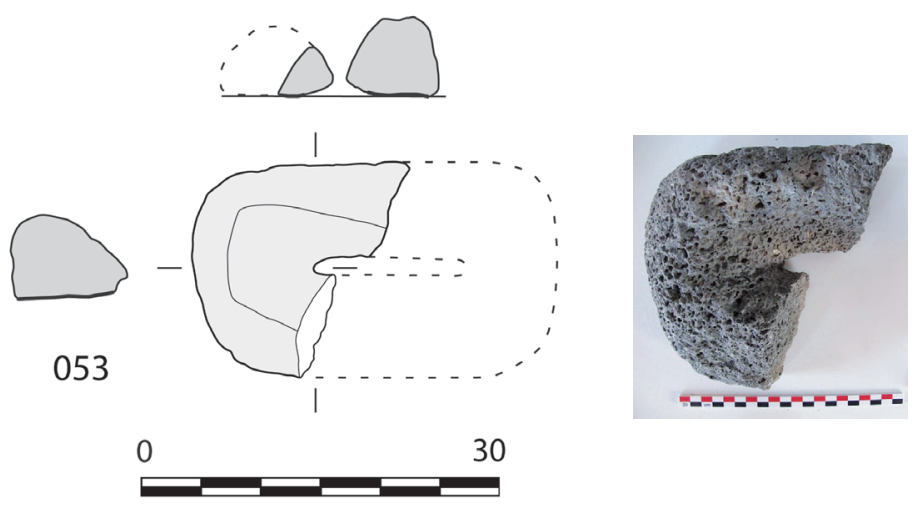

Fig. 6: Saddle quern upper stone with a central hopper. This type of quern is considered a prototype of the Olynthus mill (drawing and photograph by C. Chaigneau).

\section{Morgantina mills}

The Morgantina mill, driven with a rotary motion, consists of a bi-conical upper stone and a conical lower stone. It is named after the Sicilian inland city of Morgantina, $100 \mathrm{~km}$ west of Megara Hyblaea where many mills of this type were unearthed (White 1963, 203-204). A feature that distinguishes it from later Pompeian models is its vertical asymmetry as the upper cone, serving as a hopper, is much smaller than the lower cone. Hence the millstone is not reversible.

The assemblage of Morgantina mills at Megara Hyblaea is made up of five catilli and five metae (Fig. 7). Only one catillus is whole while another is archaeologically complete. The metae are all complete. They were hewn for the most part from dark grey or red volcanic rocks. Two are rhyolites (Williams-Thorpe 1988, 101). Four are exhibited either at the museum entrance or among sculptures in the lapidarium.

Another element that characterises the catilli is their large lateral lugs (not always symmetrical) occupying half to almost the total of its height. The lugs have rectangular cuttings that served as mortises to attach vertical wooden fittings to drive the mill. The fittings were fixed with a pin through horizontal holes pierced in the rock. Certain Morgantina catilli have opposite shallow slots and horizontal cuttings along their upper rim which served to attach either fittings for a hopper or the spindle of the meta (White 1963, 203). Two are dressed with radial furrows.

The sections of the metae are basically conical. Their diameters attain a maximum of $53 \mathrm{~cm}$ and a height ranging between 39 and $56 \mathrm{~cm}$. In general they show a symmetrical pattern of wear. Four present vertical edges along their base measuring from 10 to $20 \mathrm{~cm}$ in height. The lower part of meta no. 118 presents a very rough exterior surface $25 \mathrm{~cm}$ in height. It is possible that this lower part was intended to be buried in the ground or in a podium.

The diameters of the flat or rounded upper part of the working surfaces range from 9.5 to $22 \mathrm{~cm}$.
The dimensions of the eyes of the metae range from $12 \mathrm{~cm}$ in diameter and $4.5 \mathrm{~cm}$ in depth. The widest is $16.5 \mathrm{~cm}$ with a hole only $0.8 \mathrm{~cm}$ deep (Fig. 7, no. 117). Some eyes bear traces of iron oxide indicating they were equipped with iron spindles.

The catilli, on an average, are only $40 \mathrm{~cm}$ high suggesting that they were driven by humans and not animals like the Pompeian 'donkey mills'. Another difference with the Pompeians is their small upper cones, indicating that they are not reversible. Indeed the fittings and driving rig of this type mill are still not totally understood since few have been unearthed in situ, their wooden fittings are not preserved and they do not benefit from iconographical representations. It has been suggested that a Morgantina catillus at Carthage, for example, was equipped with horizontal levers and driven with a to-and-fro semi-rotary motion (Lancel et al. 1982, 96-100). This reconstruction remains, nonetheless, highly hypothetical.

Certain differences appear when comparing the proportion of the hopper and the grinding surface of the Morgantina catilli from the sites of Megara Hyblaea and Morgantina. The average hopper/ grinding surface proportion in Megara Hyblaea is $32 \%$ to $78 \%$, whereas the proportion at Morgantina is of $19 \%$ to $59 \%$. The hoppers of the catilli from the site of Morgantina are therefore far smaller than those of Megara Hyblaea.

Another difference is that the "sockets" of the handle lugs of the Megara Hyblaea catilli are U-shaped and open toward the top while those of Morgantina are either U-shaped or rectangular (closed) like those of the later Pompeian catilli. These differences might reflect a chronological difference. Besides, the comparison of, on the one hand, the assemblages of Megara Hyblaea and Morgantina in Eastern Sicily - with great morphological diversity - and the mills from the area of Apollonia on the northern coast of Sicily show a predominance of metae with wide, flat tops without eyes (Burgio 2008, 132; Bonnano 2009, 29-31). The general tendency toward homogenization and simplification therefore 

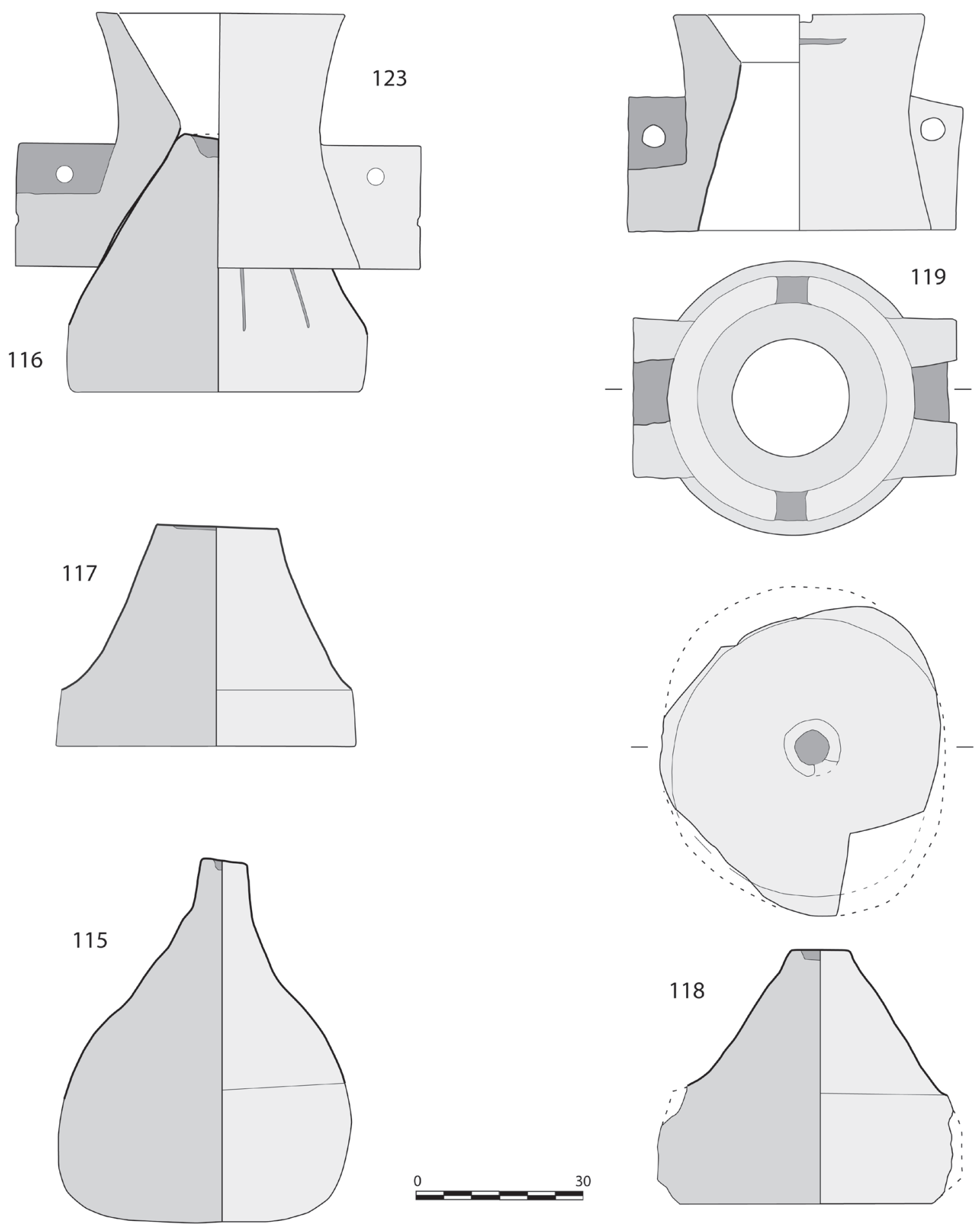

Fig. 6: Morgantina millstone (stones 123 and 116 found separately). This type is well represented in Megara Hyblaea (drawing by C. Chaigneau).

suggests that the Megara Hyblaea and Morgantina models are older.

The Morgantina model seems to characterise the Punic sphere of influence, since it has been identified in Sicily, Sardinia and Tunisia (White 1963; Canzanella 1997; Burgio 2008, 132; Bonnano 2009, 29-31; Williams-Thorpe 1989; Lancel et al.
1982, 96-100). A firm terminus ante quem for this mill type is provided by a meta brought to light in the ruins of Motya, a site that was destroyed in 397 BC (Moritz 1958, 55). This dating bolsters the accepted view that the Morgantina type precedes and is the prototype of the Roman Pompeian model. 


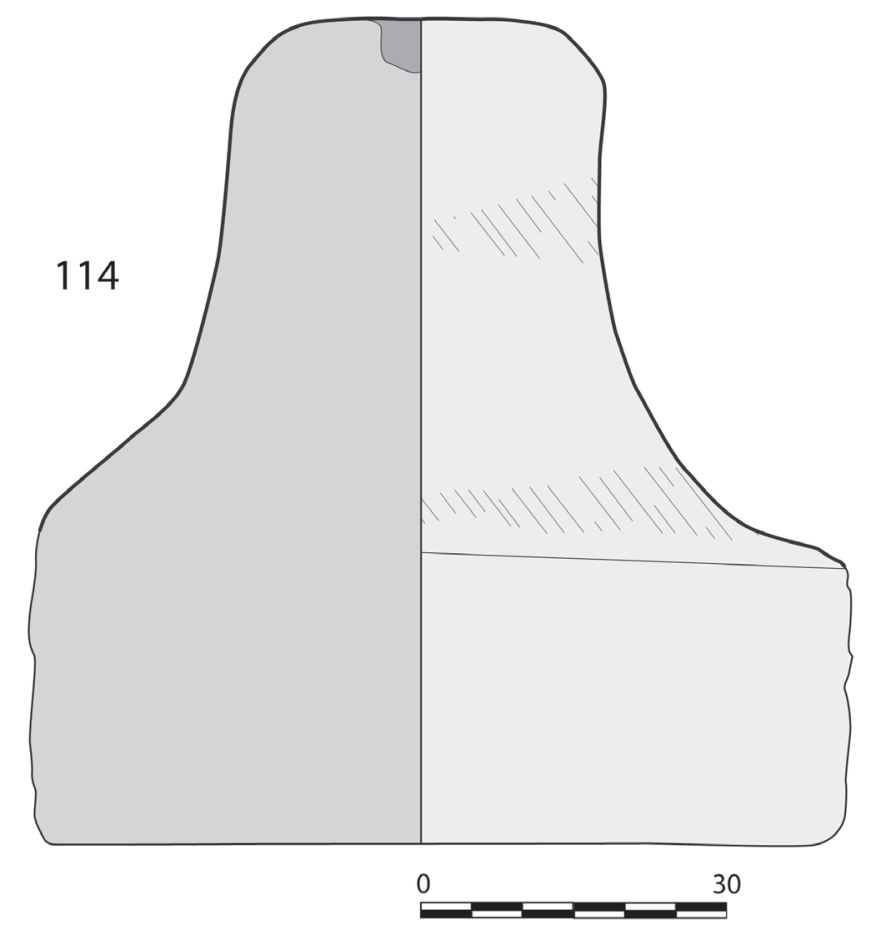

Fig. 8: Large bell-shaped meta (probably coupled with a Pompeian mill) (drawing by C. Chaigneau).

\section{A Pompeian mill?}

A roughly bell-shaped volcanic meta is $81 \mathrm{~cm}$ high and has a maximum diameter at its base of $80 \mathrm{~cm}$ (Fig. 8, no. 114). Its base has a vertical edge about $30 \mathrm{~cm}$ high before tapering to a highly worn, asymmetrical grinding surface. Its top is $32 \mathrm{~cm}$ in diameter and has a square eye $5 \mathrm{~cm}$ deep with traces of an iron spindle sealed with lead.

The dimensions and the morphology of this millstone recall the volcanic metae known in the cities of Pompeii and Ostia in Italy or the metae of ring-mills from northern Morocco (Luquet 1966; Williams-Thorpe 1988, 260) and the south of Hispania (Anderson 2016). Due to the factor of distance, an Italian provenance (Orvieto in the Vulsini volcanic district?) is much more likely than a western Mediterranean origin. There is therefore a greater probability that it corresponds to the lower stone of a Pompeian mill than to a lower stone of a ring mill.

\section{Delian mills}

The Delian mill consists of two hollow inverted trunco-conical stones with interlocking convex and concave grinding surfaces (Fig. 9). Its principal characteristic, differing from other mills of Antiquity, is that it was assembled from five to eight segments and that the upper stone or runner turns inside the lower stone (like a pot-mill). Its name derives from the Greek Island where it is the predominant rotary mill and where M. Brunet (1997) studied an example excavated in the Maison des Sceaux (House of Seals).
The Megara Hyblaea assemblage consists of 18 segments which can be broken down into 11 upper stones (corresponding to 8 different mills) and 7 lower stones, each also belonging to a different mill. No couples have been identified. Both upper and lower stones, of similar heights, have broad grinding surfaces. None show traces of dressing. Their diameters, ranging from 65 to $90 \mathrm{~cm}$, insured a higher yield of ground material compared to other smaller mills.

The Megara Hyblaea group is one of the largest and best preserved assemblages of this mill type. Furthermore, it is the westernmost representation of this mill type and the only of its type identified in Sicily. Other Delian mills are known in northern Greece and in Egypt (Brunet 1997; Peacock 2013).

The lower stone, devoid of binding fittings, was probably held together by a wooden frame. In the case of the upper stone, a channel running along the rim (either upper, lower or both) could have served, by means of wooden circle, to assemble the mill and insure the cohesion of the slabs. Furthermore, complete iron fittings are preserved on one small segment of a lower stone in the form of iron rings firmly set with lead to the upper rim. These rings could have served to attach iron cramps to the central shaft, a system that facilitated dismantling the mill for transport or maintenance. The smallest millstones bear the iron fittings only on the upper rim, while the larger models required such devices on both upper and lower rim.

Despite the discovery of the complete in situ mill in Delos, the reconstruction by Brunet (1987) has not receive unanimous support because of the lack 
of a hopper, the complexity of the assemblage or the means of traction (Peacock 2013). Moreover, Peacock recently suggested that the mill excavated by Brunet was found upside down after it was abandoned in order to extract the metal fittings (Peacock 2013). Yet it is our opinion that the wellpreserved iron fittings on the Megarian segments are evidence that confirm Brunet's reconstruction.

The fact that the mill is made up of segments has the advantage that as it was easier to manufacture (not requiring a large single monolithic block) and easier to transport after dismounting. However, mounting the elements required a high degree of precision on the part of a stone mason, a carpenter and a blacksmith. This complexity, although proof of the dexterity of the artisans, is a major drawback. Yet there is still much work to be done to fully understand the means of tentering, the system of traction and the function of the Delian mill.
073
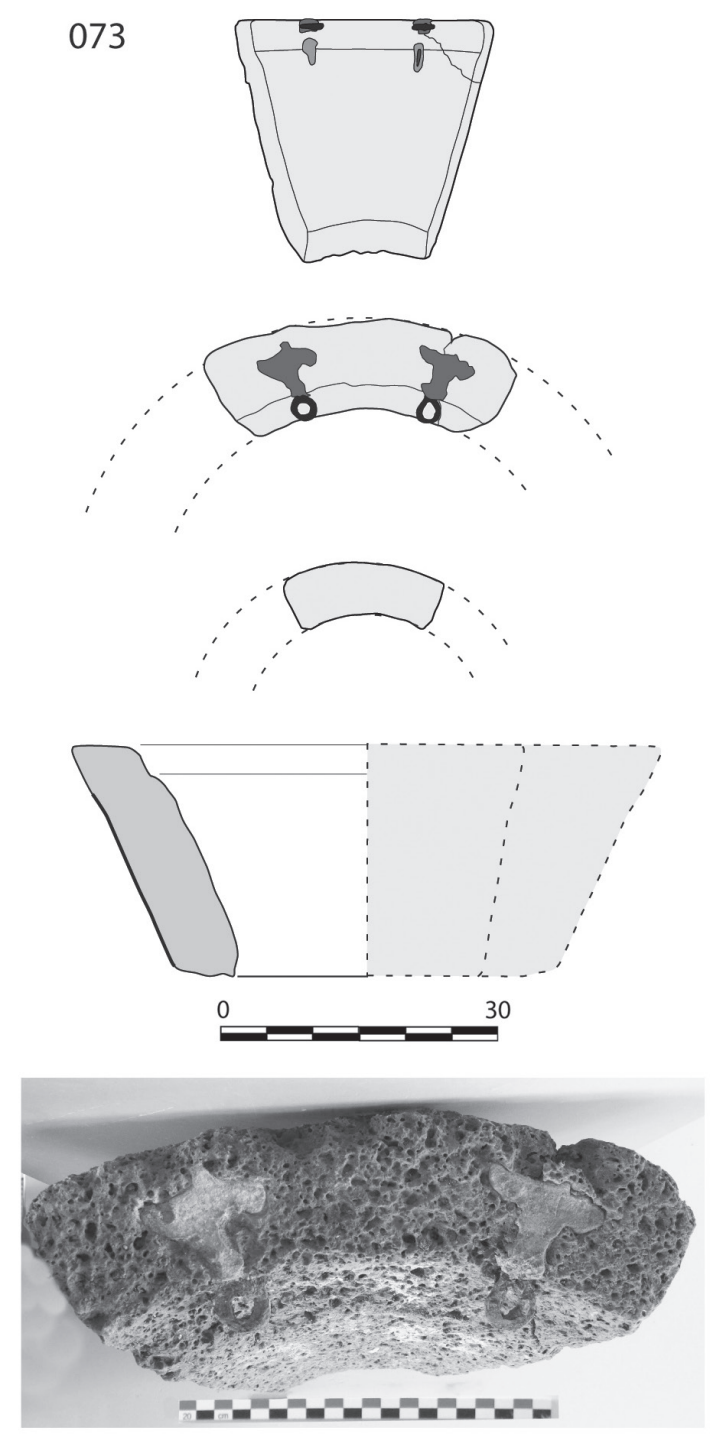
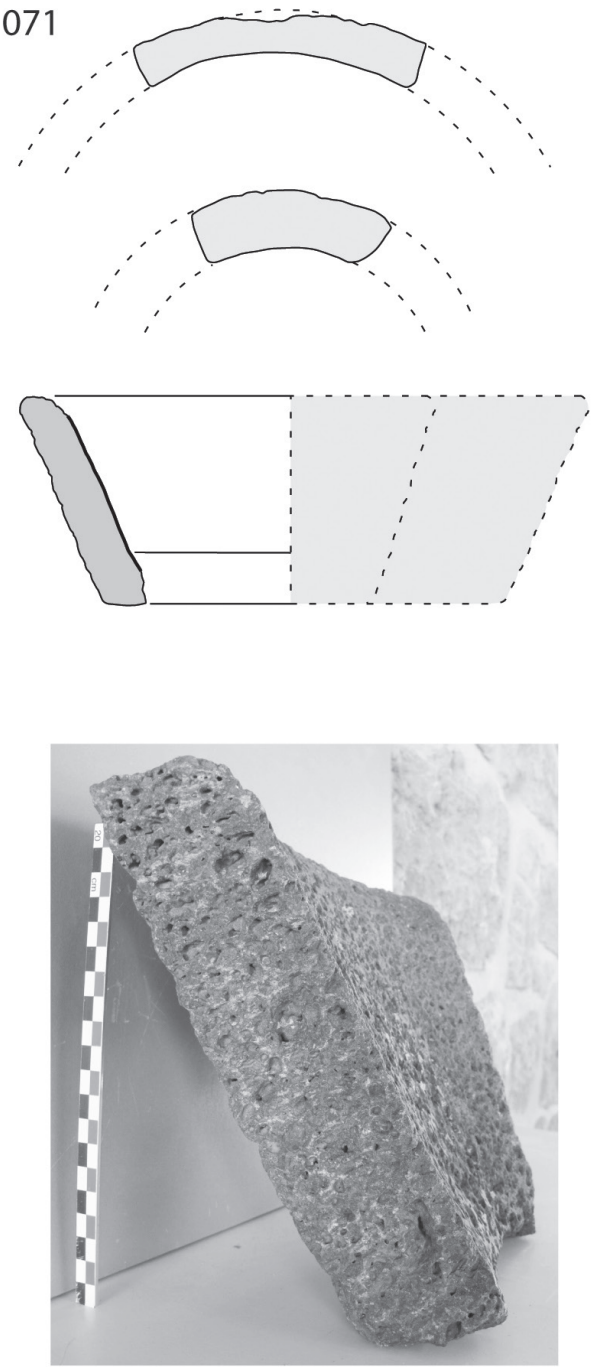

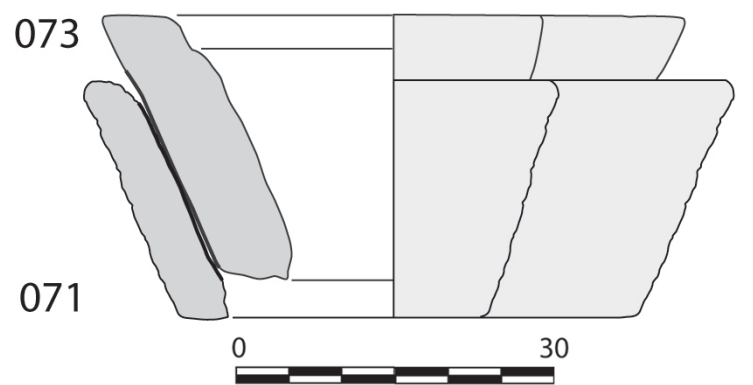

Fig. 9: Delian mills at Megara Hyblaea (no. 073: upper stone; no. 071: lower stone). The upper stone bears traces of iron cramps sealed with lead. The hypothetical reconstruction of no. 073 and 071 is meant to illustrate how the mill was mounted (drawings and photographs by C. Chaigneau). 


\section{Rotary querns}

There are only four small rotary querns at Megara Hyblaea and none is complete (Fig. 10). A catillus and meta of volcanic material (080 and 079) are relatively small and thick $(27 \mathrm{x} 14 \mathrm{~cm}$ and $31.5 \mathrm{x}$ $13.5 \mathrm{~cm})$. According to their dimensions and fittings (no visible handle hole on the catillus and a nonperforated meta eye), they resemble a complete couple found in Morgantina (White 1963, 204). Two other catilli (081 and 082), averaging $30 \mathrm{~cm}$ in diameter, are of a type of sandstone that is particularly worn. They have circular eyes and opposite rynd cuttings on the upper face (type 3B, Robin and Boyer 2011, 355) and lateral handle fittings plugged with lead. The choice of this type of sedimentary rock is especially surprising considering its fragility. It is particularly weak around the handle hole. In fact, the original cavity of a broken handle hole of the catillus was filled with a fragment of volcanic rock and sealed with lead (081) while a second handle was placed elsewhere along the edge.

\section{Discussion and conclusions}

The millstones of Megara Hyblaea, like the different phases of the city itself, are poorly dated. Their chronological distribution seem to match the traditional chronology of the city. The saddle querns therefore belong to the early period of the Archaic phase directly after the foundation of the colony in $728 \mathrm{BC}$. This mill type probably remained in use until the first years of the second phase of occupation (second half of the 4th century BC).

The second half of the 4th century BC phase is marked by the introduction of Olynthus mills in domestic contexts and the larger Morgantina mills in collective contexts such as bakeries or residences of large families.

After the destruction of the city in $213 \mathrm{BC}$, larger mills appear to have been progressively abandoned in favour of Olynthus and later small rotary querns, a mill that would appear to be better adapted to a decrease in the needs of the remaining inhabitants. The reduction of economic activity after the city's
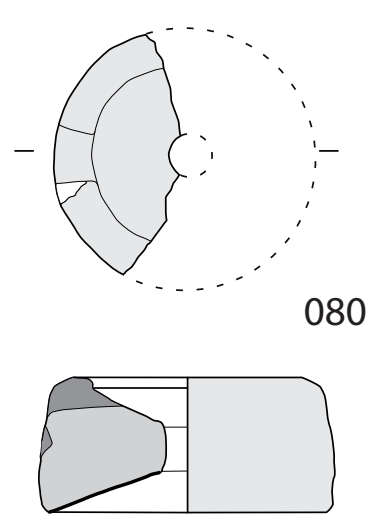
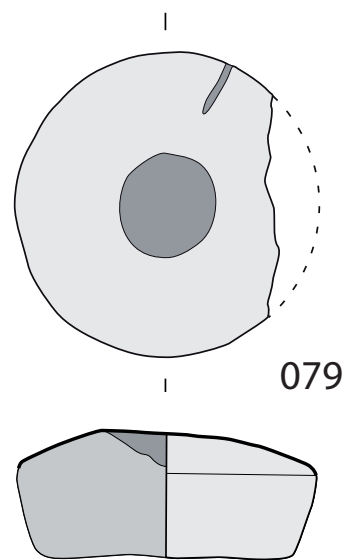

079

081

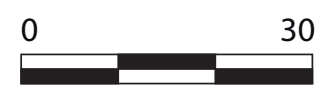

0

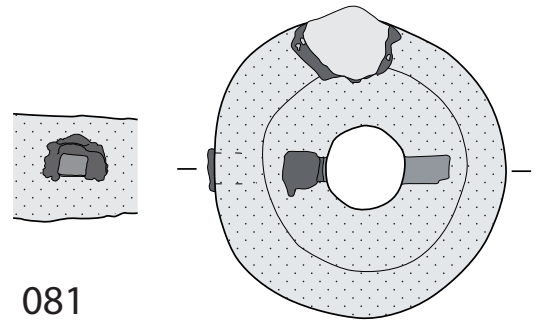

\section{Volcanic}

Sandstone

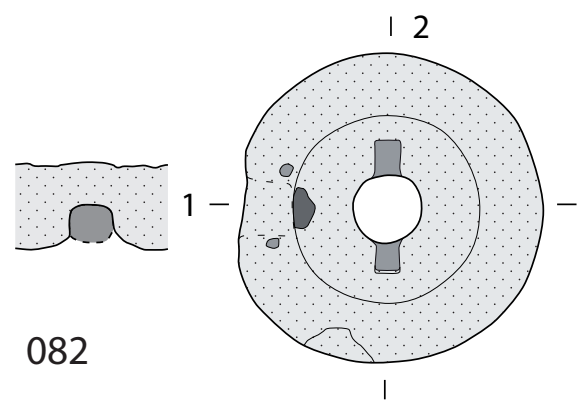

1
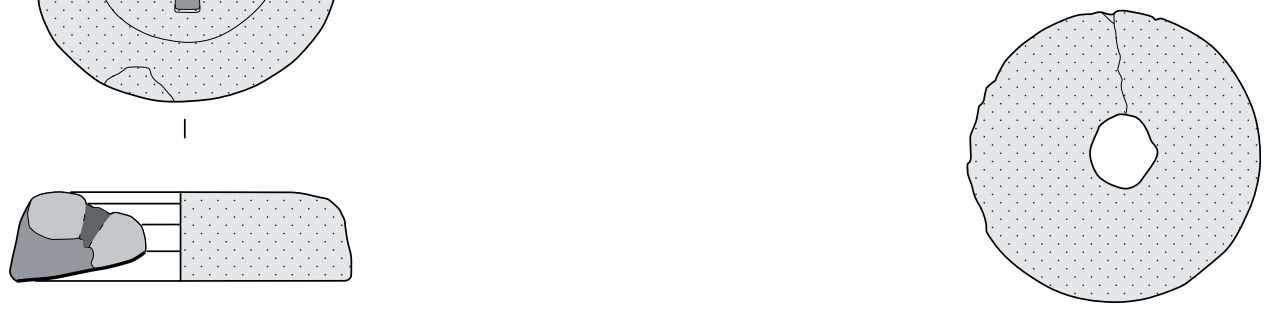

2
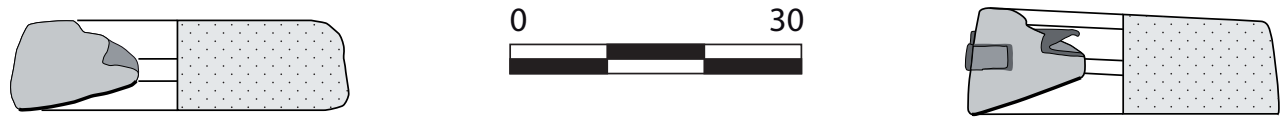

Fig. 10. Rotary querns at Megara Hyblea. The hole of the broken sandstone (081) was plugged with a fragment of volcanic rock and sealed with lead (drawings by C. Chaigneau). 


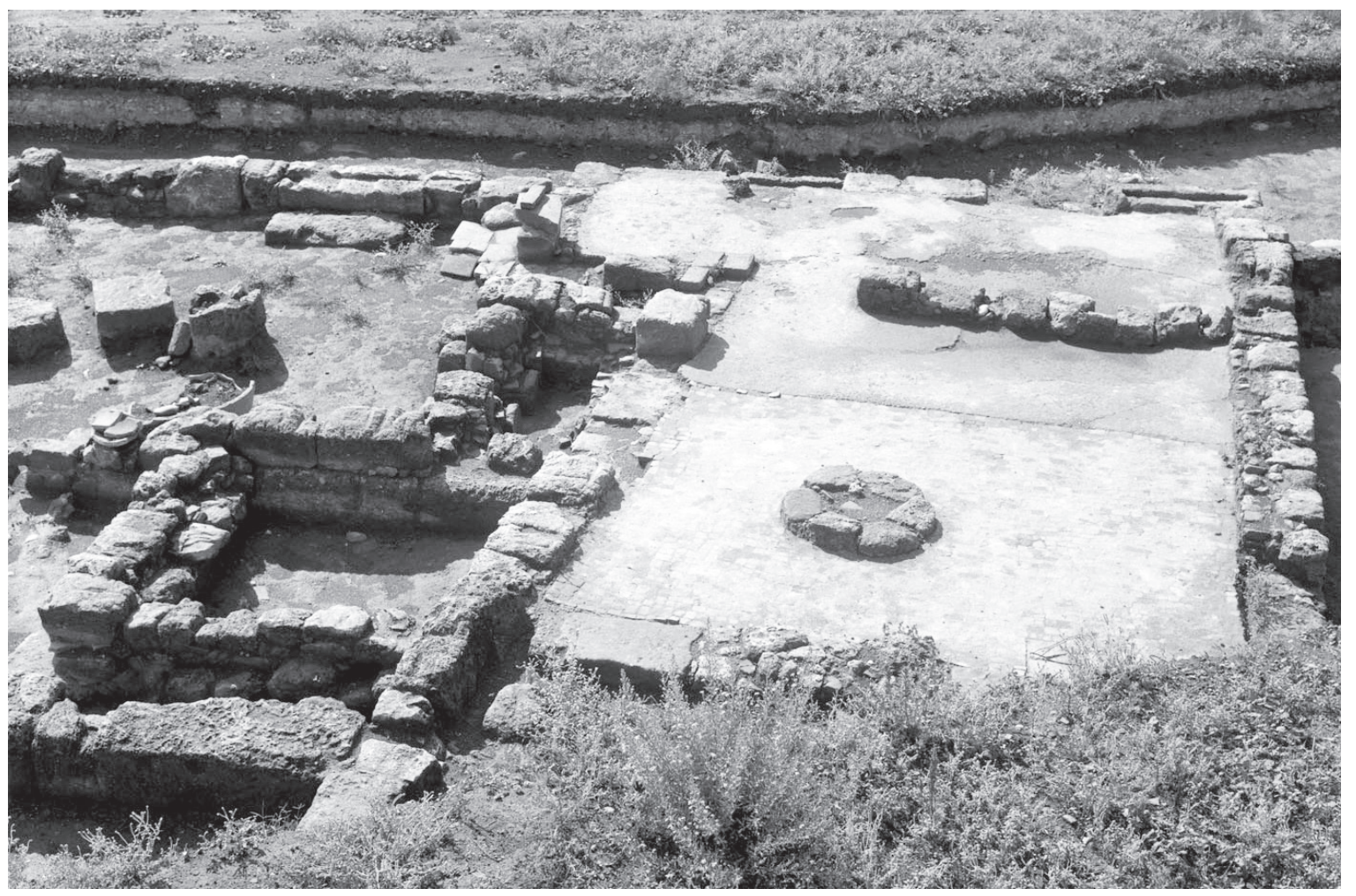

Fig. 11. Bakery identified near the city wall of Megara Hyblaea. The building measures 12 by $9 \mathrm{~m}$ and includes, in its centre, a round feature interpreted as a millstone podium (Photothèque EFR MHO 2024).

destruction might also explain the use of lower quality local sandstone instead of the more costly imported volcanic rock.

The persistence of the Olynthus mill into the first centuries $\mathrm{AD}$, contemporary to the rotary quern, is common in the western Greek settlements (Frankel 2003, 18).

The presence of the three types of large mills at Megara Hyblaea (Morgantina, Delian and presumably Pompeian) raises certain sociological and chronological questions. Their presence in the city that was reputedly sparsely inhabited leads us to either reconsider the chronology of the mills or the density of occupation of the city.

Contrary to the 'Pompeian' meta dated approximately the early 2nd century BC, the introduction of the Delian mill is far from clear. This mill type is known in Greece during the Hellenistic period, at least from the end of the 3rd century BC to the 1st century BC. Yet in Egypt it appears later, in the Late Antiquity (Brunet 1997, 35; Peacock 2013, 160-163). In both cases, Delian mills appear after the reputed destruction of Megara Hyblaea. We can therefore assume that either the economic life of the city did not come to a total stop or the city lived a brief renewal. But if the Delian mill was introduced earlier, then it would have been contemporary to the Morgantina mill and the Olynthus mill.

The diversity of types of mills in the same chronological phases appears to be characteristic of Sicily, a crossroads between the Greek, Punic and Roman cultures. Thus the Olynthus mill and the composite Delian mill are specific to the Greek civilisation, while the Morgantina type appears to come from Punic contexts.

The 'Pompeian' meta and the smaller rotary querns are from Roman contexts. The different technical traditions coexisted in different cultural contexts and related with processing different types of food stuffs.

Since no microanalysis of vegetable remains have been undertaken at Megara Hyblaea, it is not possible to identify the products that were ground in the different mills. It is commonly assumed that they were grain mills, although one case of deep grooves on a segment of a Delian mill could indicate ore grinding.

Although Sicily was known as the 'granary of Rome' (Cicero, In Verrem, II, 2) due to its fertile wheat fields, palaeobotanical analyses carried out on several Sicilian sites reveal that wheat was not predominant among the cereals and other staple foods are free-threshing species, such as hulled grain and barley associated with legumes such as bitter vetch and fava beans (Stika et al. 2008). Furthermore, these products saw different uses. Free-threshing species served for bread, whereas hulled cereals were consumed whole and roasted or roughly ground for porridges or Greek maza, a sort of barley cake.

This implies the use of at least two different types of mills. Olynthus mills were suitable for hulled grain while the Delian mill, if indeed of Greek 
tradition, might also have been used to grind grains designed for a collective use. The Morgantina mill, which evolved into the Pompeian type characteristic of the bakeries of the Roman world, was destined for the milling of wheat. It is thus most likely that a Morgantina mill was set on a podium like that brought to light in a bakery of Megara Hyblaea near the Hellenistic city wall (Fig. 11).

The bakery, poorly preserved, has four rooms and opens onto the street. It recalls the distinctive thresholds of shops such as those at Volubilis in Morocco (Luquet 1966, 312). In the largest room, probably divided in two parts considering the different opus signinum floors (with and without fragments of ceramics), several flat stones form a round base $90 \mathrm{~cm}$ in diameter.

Since this podium is only one meter from the wall, it is unlikely that the Morgantina mill was driven by an animal. An oven, a mechanical kneading trough, and some other monolithic bases, possibly serving to shape the loafs, were unearthed in the other rooms. Yet the chronology of the construction and the occupation of the bakery remain unknown.

According to a few photographs taken during the excavations, other Morgantina mills might have been in small open spaces or not to the residential area of rich houses along a plateau leading to the Archaic centre of the city. These mills could provide a clue to the diversity of types of mills and grinding practices and the evolution of the social and economic organisation of milling in Sicily.

This paper stresses the heterogeneity of Sicilian milling systems, proper to the Greek and Sicilian culture. The data regarding the Morgantina and Delian mills are especially relevant since these two types of mills are rarely published. Furthermore, the Central Mediterranean area is key to understanding the origin and the distribution of these mills. It is our hope that this preliminary study will foster other future millstone studies in Sicily and its surroundings.

\section{Acknowledgements}

This study was undertaken as part of a Master thesis supervised by Francis Prost (Université Paris 1 - Panthéon Sorbonne) in the larger framework of the study of archaeological artefacts from the Hellenistic city of Megara Hyblaea. I would also like to thank Henri Tréziny and Jean-Christophe Sourisseau (Université d'Aix-Marseille) for their assistance.

\section{Bibliography}

Anderson, T., 2016. Turning Stone to Bread, A Diachronic Study of Millstone Making in Southern Spain. Southampton Monographs in Archaeology New Series, 5, Southampton.

Arribas, A., 1987. El barco del Sec (Calvia, Mallorca), estudio de los materiales. Mallorca.

Bonanno, C., 2009. Apollonia: indagini archeologiche sul monte di San Fratello, Messina, 2003 - 2005. Rome.

BRunet, M., 1997. Les meules rotatives en Grèce, l'exemple délien. In D. Meeks and D. Garcia (eds), Techniques et économie antiques et médiévales le temps de l'innovation. Paris, 29-38.

Burgio, A., 2008. Il paesaggio agrario nella Sicilia ellenistico-romana: Alesa e il suo territorio. Roma.

Canzanella, M.G., 1997. Per uno studio della cultura materiale: le macine di Entella. In Seconde giornate internazionali di studi sull'area elima: atti, Gibellina, 22-26 ottobre 1994. Pisa, 251-90.

Chaigneau, C., 2017, Le «moulin délien»: l'apport du corpus de Mégara Hyblaea. In O. Buchsenschutz, G. Fronteau and S. Lepareux-Couturier (eds), Les meules à grain du Néolithique à l'époque médiévale: technique, culture, diffusion: actes du 2ème colloque tenu à Reims (2014), Revue archéologique de l'Est.

Frankel, R., 2003. The Olynthus mill, Its Origin and Diffusion: Typology and Distribution, American Journal of Archaeology, 107.1, 1-21.

GluhaK, T.M. and Schwall, C., 2014. Provenance Analyses of the Volcanic Rock Grinding Stones from the Greek Colony of Selinunte, Sicily (Italy) - Constraints and Possibilities, Archaeometry. doi: 10.1111/arcm.12086

Gras, M., Tréziny, H., Broise, H., Pelagatti, P. and VozA, G., 2004. Mégara Hyblaea. 5, l'espace urbain d'une cité grecque de Sicile orientale. Rome.

Lancel, S., Morel, J.-P. and Thuillier, J.-P., 1982. Byrsa II. Rapports préliminaires sur les fouilles 1977-1978: niveaux et vestiges puniques. Rome.

LuQueT, A., 1966. Blé et meunerie à Volubilis, Bulletin d'archéologie marocaine, 6, 301-16.

Moritz, L. A., 1958. Grain-Mills and Flour in Classical Antiquity. New York.

Peacock, D.P.S., 2013. Segmented Mills in Classical Antiquity. In J. PoBlome (ed.), Exempli Gratia. Sagalassos, Marc Waelkens and Interdisciplinary Archaeology, 153-persistence 64.

Robin, B. and Boyer, F., 2011. La liaison des meules rotatives manuelles protohistoriques et gallo- 
romaines : œil et anille. In Évolution typologique et technique des meules du Néolithique à l'an mille actes des IIIe rencontres archéologiques de l'Archéosite gaulois. Bordeaux, 351-58.

Stika, H.-P., Heiss, A.G., and ZACH, B., 2008. Plant remains from the early Iron Age in western Sicily: differences in subsistence strategies of Greek and Elymian sites. Vegetation History and Archaeobotany, 17.1, 139-48.

White, D., 1963. A Survey of Millstones from Morgantina, American Journal of Archaeology, 67.2, 199-206.
Williams-Thorpe, O., 1988. Provenancing and Archaeology of Roman Millstones from the Mediterranean Area, Journal of Archaeological Science, 15, 253-305.

Williams-Thorpe, O., 1989. Provenancing and Archaeology of Roman Millstones from Sardinia (Italy), Oxford Journal of Archaeology, 8, 1, 89-117.

Williams-Thorpe, O. and Thorpe, R.S., 1990. Millstone provenancing used in tracing the route of a fourthcentury BC Greek merchant ship, Archaeometry, 32, 115-37. 